Note

\title{
BASIL PLANTS GROWTH AND ESSENTIAL OIL YIELD IN A PRODUCTION SYSTEM WITH SUCCESSIVE CUTS $\left({ }^{1}\right)$
}

\author{
ANDRÉ MAY $\left({ }^{2 *}\right)$; ODAIR ALVES BOVI $\left({ }^{3}\right)$; NILSON BORLINA MAIA $\left({ }^{3}\right)$; LAURO EUCLIDES SOARES \\ BARATA $\left({ }^{4}\right)$; RITA DE CASSIA ZACARDI DE SOUZA $\left({ }^{5}\right)$; EDUARDO MATTOSO RAMOS DE SOUZA $\left({ }^{5}\right)$, \\ ANDREA ROCHA ALMEIDA DE MORAES $\left({ }^{5}\right)$; MARIANE QUAGLIA PINHEIRO $\left({ }^{6}\right)$
}

\begin{abstract}
This work studied the growth of basil plants and the effect of successive cuts on the total yield and quality of the essential oil, throughout the crop cycle. Steady increases were observed in the dry weight of the aerial part and in the essential oil yield, during the cultivation cycle. Intensive cultivation and successive cuts could improve the agronomical and industrial yield in each harvest.
\end{abstract}

Key words: Ocimum basilicum L., dry mass, harvest intervals.

\section{CRESCIMENTO DE PLANTAS DE MANJERICÃO E PRODUÇÃO DE ÓLEO EM SISTEMA DE PRODUÇÃO COM CORTES SUCESSIVOS \\ RESUMO}

Esta pesquisa visou estudar o crescimento de plantas de manjericão e o efeito de cortes sucessivos sobre a produção e qualidade do óleo essencial ao longo do ciclo. Observou-se aumento na massa seca da parte aérea e na produção de óleo essencial ao longo do ciclo de cultivo. $\mathrm{O}$ cultivo do manjericão submetido a cortes sucessivos pode aumentar a produção do óleo em cada colheita.

Palavras-chave: Ocimum basilicum L., massa seca, intervalo entre cortes.

(1) Recept for publication in July 6, 2006 and accept in September 28, 2007.

$\left({ }^{2}\right)$ Rua Padre Vieira, 600, Ap. 31, Centro, 13015 -120 Campinas (SP).E-mail: mayandre@bol.com.br $\left(^{*}\right)$ autor correspondente.

$\left({ }^{3}\right)$ Instituto Agronômico, Caixa Postal 28, 13012-970 Campinas (SP)

( $\left.{ }^{4}\right)$ Instituto de Química, UNICAMP, Caixa Postal 6154, 13083-970 Campinas (SP). E-mail: lbarata@iqm.unicamp.br

$\left({ }^{5}\right)$ Master Degree.

$\left({ }^{6}\right)$ Biology student. 


\section{Introduction}

Basil (Ocimum basilicum L.) is included in the Lamiaceae family, which has about 3500 species distributed among 210 genera, most of these herbaceous, less often shrubs, or rarely trees. Herbaceous plants from this family can behave like annual or perennial plants, depending on where and how they are grown (BLANK et al., 2004). In Brazil, they are cultivated by small farmers mainly to supply fresh or dry leaves as flavorants or condiments (TEIXEIRA et al., 2002).

Besides fresh leaves have been normally used in natura, one can extract a valuable essential oil from basil, used in the manufacture of perfumes and flavors for food and beverages (MAROTTI et al., 1996). The basil essential oil also has insecticide and insect repellent properties (UMERIE et al., 1998). MAIA et al. (1996) reported the potential uses of basil essential oil in order to replace molecules obtained from endangereds species.

Basil essential oil can be extracted from leaves and flowering tops through hydrodestillation (CHARLES AND SIMON, 1990). The chemical composition of basil extracts reveals the presence of tanines, flavonoids, saponins, and volatile terpenes like camphor, tymol, methylchavicol, linalool, eugenol, 1-8-cineol and pinenes (LORENZI AND MATOS, 2002). The composition essential oil may reveal several types of basil like the European, the French or so called sweet basil, the Reunion or Comores, the Bulgar, the Java or Methyl Cinnamante and the Eugenol (SIMON et al., 1990). The most valuable basil essential oil in the market is the European type, which is mainly constituted by linalool (40,5 to $48,2 \%)$ and methyl-chavicol $(28,9$ to 31,6\%) (Fleisher, 1981; Charles AND Simon, 1990). The price for the most valuables basil oils in the market reach values up to US\$110,00/ $\mathrm{kg}$. This price makes the cultivation of basil for essential oil production a promising alternative for small farmers in Brazil.

The production of basil essential oil has increased the demand for basil vegetal matter to be extracted in specialized distilleries, thus creating a need of fresh plants from periodical harvest of semiperennial plants. Few works have been done about seasonal variation of basil oil yield during the year (Muni et al., 2002) and about oil production as a function of the number of plants per area (GILL AND RANDHAWA, 2000).

The economical interest of some vegetable species for essential oil production has brought the need of studies about the capacity of them to bear intense exploitation when submitted to frequent harvesting, aiming to reach the maximum longevity of the plants. However, the knowledge about basil cultivation in this intensive system is almost inexistent (FERNANDES et al., 2004).

FERNANDES et al. (2004) has observed, in a study about hydropony basil cultivation on different substrates, in protected environments, that the major substances in basil essential oils were linalool, atrans-bergamoptene, germecrene-D, cubenol and g-cadinene. Linalool was the most abundant compound, both in the narrow leaf basil ( 44,3 to 59,8 $\%$ ) and in the broad leaf basil (22,7 to $37,4 \%)$.

Studies on selection of linalool-rich genotypes with 55 Ocimum sp. accesses in the Germplam Databank of the Federal University of Sergipe, revealed 6 plants with superior oil yield and linalool contant: NSL6421 (81,40\% linalool), PI358464 (79,38\% linalool), PI531396 (78,30 \% linalool), PI414194 (71,62 $\%$ linalool), PI197442 (61,57 \% linalool) and 'Fino Verde' (77,04 \% linalool) (BLANK et al., 2004).

\section{Materials and Methods}

The experiment was carried out in the Horticulture Agribusiness Analysis and Technological Research Experimental Center of the Agronomic Institute (IAC) in Campinas - SP, during May $30^{\text {th }}$ 2005 and May, 30 2006.

Herbaceus branches with two leaves were grown in trays in a nursery, up to rooting. The cuttings were collected in the Aromatic and Medicinal Plant Center of the IAC. Afther 30 days in trays, the cuts were planted with a interval of $0,6 \mathrm{~m} \times 0,4 \mathrm{~m}$.

The experiment was carried out in a completely randomized block design, with eight replications. A conventional sprinkling system was used for the irrigation.

There were applied $5 \mathrm{~kg} \mathrm{~m}^{-2}$ of manure, according to the recommendations of CÔRREA JÚNIOR et al. (1994) for basil cultivation.

The plots were cut every other 42 days at 40 $\mathrm{cm}$ from soil surface. Eigth harvesting seasons were made since June $25^{\text {th }}$ of 2005 .

Plant growth analysis method by MAGALHÃES (1986), describes physiological and morphological conditions of plants in different time intervals, allowing to observe the production dynamic, evaluated by means of physiological and biochemical indexes.

For each harvest was measured the leaves and branches dry mass, the plants height and the essential oil yield. Essential oil was extract from $150 \mathrm{~g}$ of branches and leaves (aerial part) in a Clevenger-type apparatus, for 120 minutes. 
Manual separation of leaves and branches were made to evaluate mass production in different parts of the plant, and then dried in an forced air oven, at $60^{\circ} \mathrm{C}$, and weighed until constant mass weight.

To get the centesimal composition of the basil essential oil, eight sample were analyzed in a GC-MS $5890 / 5970$ with a column HP5-MS (30m x 0,25mm x $0,25 \mathrm{um}$ ) (one sample for each cut to evaluated de essential oil composition during the experimental period). The temperature ramp was: $\mathrm{T}_{\text {initial }}: 50{ }^{\circ} \mathrm{C}$, ramp $\left(5{ }^{\circ} \mathrm{C} / \mathrm{min}\right) \mathrm{T}_{\text {final }}: 220^{\circ} \mathrm{C}, \mathrm{T}_{\text {injector }}: 250^{\circ} \mathrm{C}, \mathrm{T}_{\text {detector }}$ : $280^{\circ} \mathrm{C}$. Split rate $(1: 100)$. The essential oil samples were diluted at $10 \mathrm{mg} / \mathrm{ml}$. Pentadecane at $3 \mathrm{mg} / \mathrm{ml}$ was used as a marker. The injected samples consisted of $0,8 \mathrm{ml}$ of the diluted essential oil and $0,2 \mathrm{ml}$ of diluted pentadecane. The solvent for all samples was methylene chloride. The compound identification was made by comparison of the mass spectra obtained and the ones included in the Wiley 275 mass spectra library and by its calculated retention index (Kovat's index - KI), according to methodology described by ADAMs (1995).

The data obtained were fitted by polynomial regressions using the software ESTAT (UNESP, Jaboticabal - SP).

\section{Results ans Discussion}

Production of dry matter of leaves, branches, total aerial mass, plant height and essential oil yield were fitted in a quadratic polynomial regression (Figures 1, 2 and 3). It was noted a fast initial growth with constant increments in the amount of dry matter and in the plants height, up to the maximum values achieved, followed by a subsequent decrease. The maximum values for the analyzed data are presented in table 1.

The analysis of the data shows a higher dry mass production, of the total aerial part, at around 234 days after planting (DAP) or at the sixth cut (Figure 1) and high plant at $213 \mathrm{DAP}$, or fifth cut (Figure 2). The essential oil yield was not affected by the numbers of cuts. The total essential oil production in the eight cuts was of $1157 \mathrm{~kg} \mathrm{ha}^{-1}$.

It was noted a reduction in production of aerial parts after the fifth cut, and a gradual decrease of sprouts, reducing the growth speed and increasing plants senescence. Although basil is considered a perennial plant in warm regions (CÔRREA JÚNIOR et al., 1994), when submited to successive and intense harvests, it has an annual behavior. So in commercial cultivations, when the objective is to achieve maximum oil production per area, the crop renewal may be necessary

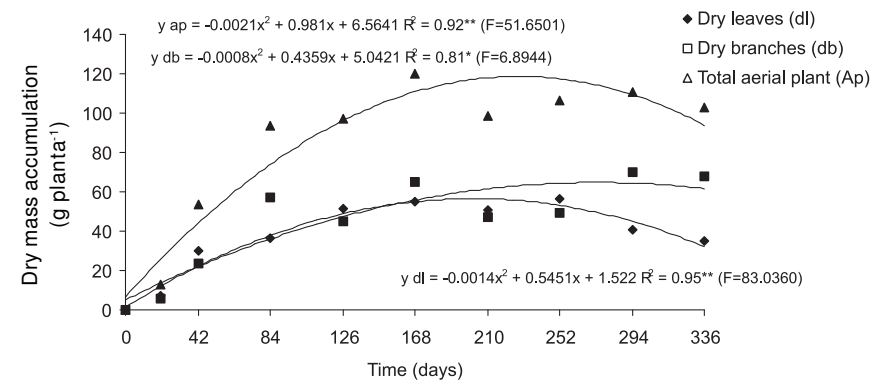

Figure 1. Dry mass accumullation for basil leaves, branches and the whole aerial plant in a 13 month interval. Agronomic Institute, 2007.

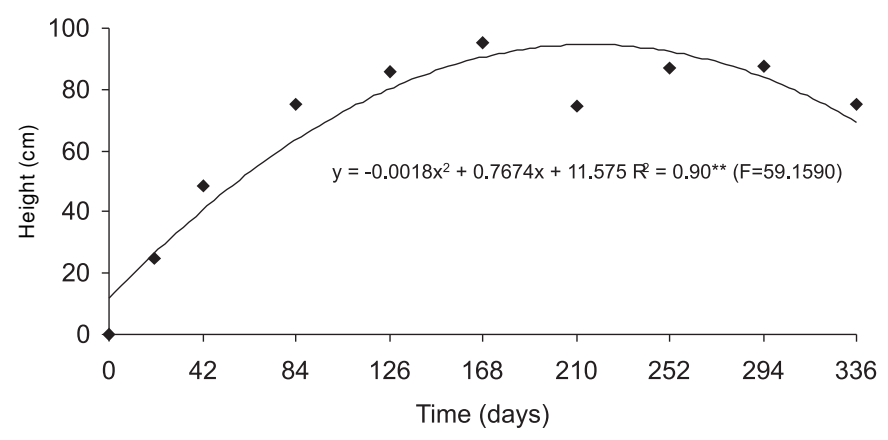

Figure 2. Height plant in a 13 month interval. Agronomic Institute, 2007.

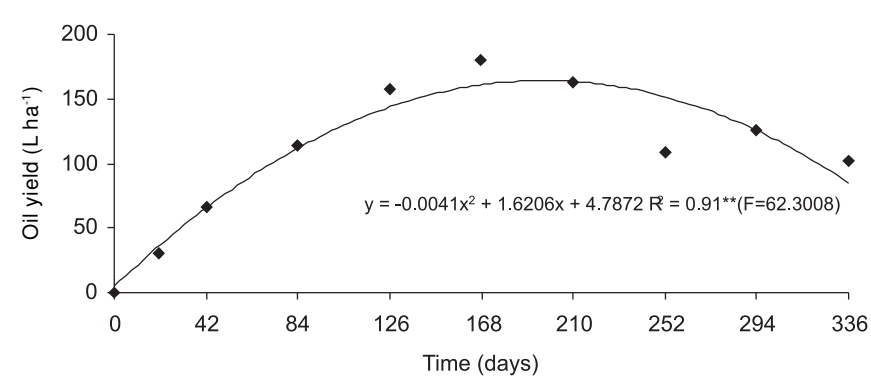

Figure 3. Oil yield from fresh matter of the total aerial part during the whole growth cycle of basil plants. Agronomic Institute, 2007.

Table 1. Maximum results obtained for dry masses of leaves, branches and total aerial part, plant height and essential oil yield. Agronomic Institute, 2007

\begin{tabular}{|c|c|c|}
\hline $\begin{array}{l}\text { Variable } \\
\text { Unit }\end{array}$ & $\begin{array}{l}\text { Days after } \\
\text { planting }\end{array}$ & $\begin{array}{l}\text { Maximum } \\
\text { value }\end{array}$ \\
\hline $\begin{array}{l}\text { Dry mass of } \\
\text { leaves }\left(\mathrm{g} \mathrm{plant}^{-1}\right)\end{array}$ & 195 & 54.6 \\
\hline Dry mass of branches (g plant ${ }^{-1}$ ) & 272 & 64.4 \\
\hline $\begin{array}{l}\text { Dry mass of the total } \\
\text { aerial part }\left(\mathrm{g} \mathrm{plant}^{-1}\right)\end{array}$ & 234 & 121.1 \\
\hline Plant height $(\mathrm{cm})$ & 213 & 93.4 \\
\hline Essential oil yield $\left(\mathrm{kg} \mathrm{ha}^{-1}\right)$ & 198 & 164.9 \\
\hline
\end{tabular}


Despite the fact that CORRÊA JÚNIOR et al. (1994) have mentioned that the first harvest should be done just after the second year of cultivation, in this work, superior results were obtained, as showed in Figure 1 , a constant aerial part growth up to 234 days after planting. The dry mass of aerial parts accumulated along the experimental period was of $33,13 \mathrm{t} \mathrm{ha}^{-1}$, $\left(15,15 \mathrm{t} \mathrm{ha}^{-1}\right.$ of dry leaves). CORRÊA JúNIOR et al. (1994) mentioned a dry mass annual production of the aerial part of $3 \mathrm{t} \mathrm{ha}^{-1},\left(1,5 \mathrm{t} \mathrm{ha}^{-1}\right.$ of dry leaves) with planting space of $0,6 \mathrm{~m} \times 0,25 \mathrm{~m}$.

Along the experimental period there was observed an air temperature increase. But even at the time of decreasing production of aerial part mass, which happened between late January (fifth harvest, day 210) and the beginning of March (sixth harvest, day 252), temperatures were suitable (between 20 and $27{ }^{\circ} \mathrm{C}$ ) for basil development (Figure 4). Plant senescence was a consequence of intensive harvest rather than weather conditions.

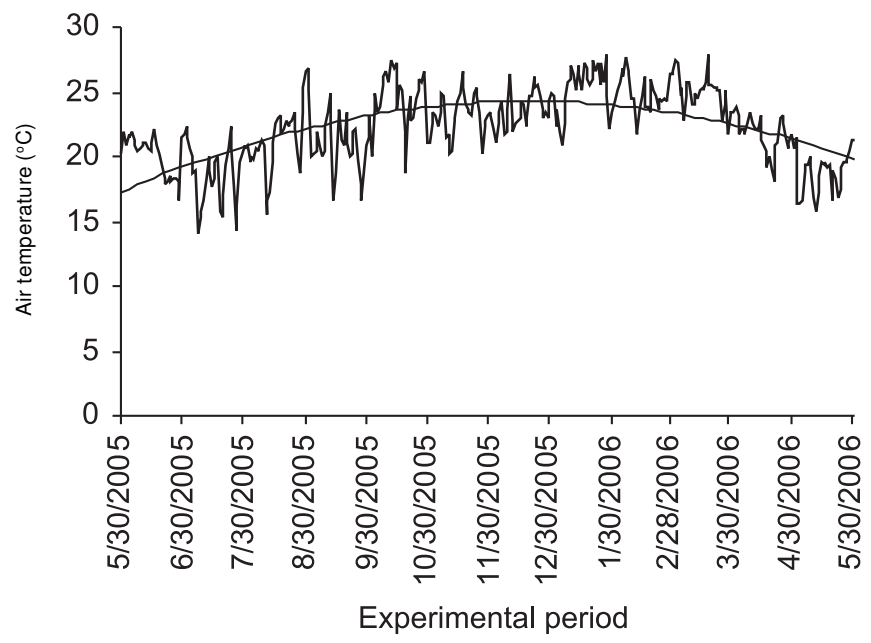

Figure 4. Average air temperature along the experiment period. Agronomic Institute, 2007.

The dry mass of leaves was similar to the dry mass of branches up to day 168 (fourth harvest Figure 1), when there was a reduction in the ratio leaves/branches. The highest concentrations of essential oil are in the leaves, once that the higher amount of leaves dry mass was on the $195^{\text {th }}$ day and the maximum yield of essential oil was on the $198^{\text {th }}$ day, that is, the maximum values achieved for both variables are very time-related. So, one can conclude that for maximum basil essential oil production, it is important to keep a high ratio leaves/branches. However, even with high temperatures in the period of maximum production, the studied species did not keep high proportion between the production of leaves and branches as a consequence of the natural senescence caused by intensive exploitation.
Essential oil from branches, close to zero, is not economically considerable. Maximum ratio of leaves and branches must be achieved to maximize oil production.

The essential oil yield achieved in the present work, $0.58 \%$, by the basis weight of fresh leaves is superior to the value reported by FERNANDES et al. (2004) when cultivating hydroponics broad leaf basil in a greenhouse. It was also superior then the $0.3 \%$ obtained by CORRÊA JÚNIOR et al. (1994) from fresh aerial parts.

Essential oil composition varied during the experimental period. Linalool content increased until the fourth cut on day 168 reaching $43.58 \%$, decreasing afterwards until the end of the experiment with $31.73 \%$. The same pattern occurred with camphor from $3.60 \%$ in the beginning reaching a maximum of $12.75 \%$ and decreasing to $11.72 \%$ at the end. Eugenol content varied from $7.87 \%$ in day 126 to $18.43 \%$ in day 336. Cineol varied form $0.33 \%$ in day 84 to $8.08 \%$ in day 336. Alpha terpineol varied from 3.43 in day 42 to $2.14 \%$ in day 210 .

\section{Conclusion}

The essential oil production in this intensive harvesting system produced high yields in the period of the experiment, but anticipates plant senescence. It has been verified that the essential oil is mainly concentrated in the leaves and that the oil amount in the branches is almost insignificant.

\section{References}

ADAMS, R.P. Identification of Essential Oils Components by Gas Chromatography/Mass Spectrometry. 2.ed. Allured Publishing, 1995. $469 \mathrm{p}$

BLANK, A.F.; CARVALHO FILHO, J.L.S. de; SANTOS NETO, A.L. dos, ALVES, P.B. ; ARRIGONI-BLANK, M.F.; SILVAMANN, R.; MENDONÇA, M.C. Caracterização morfológica e agronômica de acessos de manjericão e alfavaca. Horticultura Brasileira, Brasília, v.22, p.113-116, 2004.

CHARLES, D.J.; SIMON, J.E. Comparison of extraction methods for the rapid determination of essential oil content and composition of basil (Ocimum spp.). Journal of the American Society for Horticultural Science, Alexandria, v.115, n.3, p.458-462, 1990.

CORRÊA JÚNIOR, C.; MING, C.L.; SCHEFFER, M.C. Cultivo de plantas medicinais, condimentares e aromáticas. Jaboticabal: FUNEP, 1994. 162 p.

FERNANDES, P.C.; FCANALI, R. TEIXEIRA, J.P.F.; FURLANI, P.R.;MARQUES, M.O.M. Cultivo de manjericão em hidroponia em diferentes substratos sob ambiente protegido. Horticultura Brasileira, Brasília, v.22, n.2, p.260-264, 2004. 
FLEISHER, A. Essential oils from two varieties of Ocimum basilicum L. grown in Israel. Journal of the Science of Food and Agriculture Abstracts, Oxford, v.32, p.1119-1122, 1981.

GILL, B.S.; RANDHAWA, G.S. Effect of different row and plant spacings on yield and quality of French basil oil. Journal of Research Punjab Agricultural University, Ludhiana,v. 36, n. 3-4, p. 191-193, 2000.

LORENZI, H.; MATOS, F.J.A. Plantas medicinais no Brasil: nativas e exóticas. Nova Odessa: Instituto Plantarum, 2002. 252 p.

MAGALHÃES, A.C.N. Análise quantitativa de crescimento. In: FERRI, M.G. Fisiologia vegetal. São Paulo: EDUSP, 1986. p. 331-350.

MAIA, N.B.; BOVI, O.A.; PERECIN, M.B.; MARQUES, M.O.M.; GRANJA, N.P.; TRUJILLO, A.L.R. New crops with potential to produce essential oil with high linalool content helping preserve rosewood - an endangered Amazon species. Acta Horticulturae, Wageningen, p.39-43, 1996.
MAROTTI, M., PICCAGLIA, R., GIOVANELLI, E. Differences in essential oil composition of Basil (Ocimum basilicum L.) italian cultivars related to morfological characteristics. Journal of Agricultural Food Chemistry, Washington, v.44, n.12, p.39263929, 1996.

MUNI, R.; DASHA, R.; NAQVI, A.A.; SUSHIL, K. Effect of plant density and harvesting time on the yield and the quality of essential oil in Ocimum species. Journal of Medicinal and Aromatic Plant Sciences, v. 24, n. 2, p. 393-396, 2002.

SIMON, J.E.; QUINN, J.; MURRAY, R.G. Basil: a source of essential oils. In: JANICK, J.; SIMON, J.E. (Eds.). Advances in new crops. Portland: Timber Press, 1990. p. 484-489.

TEIXEIRA, J.P.F.; MARQUES, M.O.M.; FURLANI, P.R.; FACANALLI, R. Essential oil contents in two cultivars of basil cultivated on NFT-hydroponics, Acta Horticulturae, Wageningen, v. 569, p.203-208, 2002.

UMERIE, S.C., ANASO, H.U.; ANYASORO, L.J.C. Inseticidal potentials of Ocimum basilicum leaf extracts. Bioresource Technology, v.64, n.3, p.237-239, 1998. 